\title{
Depletion of complement system immunity in patients with myocardial infarction
}

\author{
WENWEN YAN $^{1}$, LIN CHE $^{1}$, JINFA JIANG $^{1}$, FAN YANG $^{2}$, QIANGLIN DUAN ${ }^{1}$, \\ HAOMING SONG ${ }^{1}$, XIAOHONG LIU ${ }^{1}$, YUQIN SHEN ${ }^{1}$ and LEMIN WANG ${ }^{1}$ \\ Departments of ${ }^{1}$ Cardiology and ${ }^{2}$ Laboratory Medicine, Tongji Hospital, Tongji University School of Medicine, \\ Shanghai 200065, P.R. China
}

Received September 22, 2015; Accepted October 11, 2016

DOI: $10.3892 / \mathrm{mmr} .2016 .5912$

\begin{abstract}
The aim of the present study was to evaluate differences in the expression of complement system genes, and serum levels of $\mathrm{CH} 50, \mathrm{C} 3$ and $\mathrm{C} 4$ in peripheral blood mononuclear cells from patients with myocardial infarction (AMI), stable angina pectoris (SA) and controls. A total of 100 patients with AMI, 100 with SA and 100 clinical controls were recruited in the present study. In each group, 20 randomly selected individuals were examined using whole human genome microarray analysis to detect the expression of genes of the complement system. The serum levels of CH50, C3 and $\mathrm{C} 4$ were measured in all 300 subjects. In the patients with AMI, the expression levels of genes encoding $\mathrm{Clq} \alpha, \mathrm{Clq} \beta, \mathrm{Clq} \gamma, \mathrm{Clr}$, Factor P, C5a (complement component), CR1, integrin $\alpha \mathrm{M}$, integrin $\alpha \mathrm{X}$, integrin $\beta 2, \mathrm{C} 5 \mathrm{aR}, \mathrm{CRIg}$ (complement receptors) and CD46, CD55 and CD59 (complement regulators) were significantly higher, compared with the respective genes in the SA patients and controls $(\mathrm{P}<0.05)$, whereas the mRNA levels of $\mathrm{C} 1 \mathrm{~s}, \mathrm{C} 7, \mathrm{C} 8 \mathrm{\beta}$ and $\mathrm{C} 9$ were the lowest in this group $(\mathrm{P}<0.05)$. No statistically significant differences were found in the gene expression levels of complement components or regulators between the SA and control groups. The serum levels of $\mathrm{CH} 50, \mathrm{C} 3$ and $\mathrm{C} 4$ were significantly increased in the AMI and SA groups, compared with the controls. In the AMI and SA groups, the complement system was activated. However, the differential mRNA expression of complement components, receptors and regulators in the AMI group suggested the dysfunction of the C5b-9 complex. The depression of complement system immunity in the patients with AMI may be associated with the pathogenesis of AMI.
\end{abstract}

Correspondence to: Dr Yuqin Shen or Dr Lemin Wang, Department of Cardiology, Tongji Hospital, Tongji University School of Medicine, 389 Xincun Road, Putuo, Shanghai 200065, P.R. China

E-mail: wanglemin@tongji.edu.cn

E-mail: sy_1963@126.com

Key words: myocardial infarction, stable angina pectoris, complement immunity, gene expression

\section{Introduction}

Coronary atherosclerotic diseases (CADs) are a leading contributor to morbidity and mortality rates in the modern world, and there is increasing evidence that atherosclerosis is a chronic inflammatory disease (1). However, previous data obtained from animal models and clinical studies have suggested that the complement system is important in the pathogenesis of CADs, and is also involved in the progression of inflammation and thrombosis (2-5).

The complement system is an innate cytotoxic host defense system, which normally functions to eliminate foreign pathogens and self-particles, and can be activated via three mechanisms, termed the classical, lectin or alternative pathways. The initiation of each pathway eventually results in the formation of the terminal C5b-9 complex, or the membrane attack complex (MAC), which is primarily responsible for cell lysis (6). Activation of the complement system also results in the production of numerous effector molecules with potent biological activities, including complement-mediated opsonization and phagocytosis by $\mathrm{C} 3 \mathrm{~b}, \mathrm{C} 4 \mathrm{~b}$ and ic $3 \mathrm{~b}$, recognized by complement receptors, and anaphylatoxin production through $\mathrm{C} 3 \mathrm{a}, \mathrm{C} 4 \mathrm{a}$ and $\mathrm{C} 5 \mathrm{a}$ (7).

According to the results of clinical studies, monomeric C-reactive protein, myocardial necrosis and apoptotic cells may serve as potent activators of the complement system (8-10). However, the extent of activation of the complement system in different forms in CAD remain to be fully elucidate. For stable angina pectoris (SA) in particular, a limited number of studies have been performed, the majority of which have produced controversial results (11-14). The complement system is composed of $>30$ proteins, including complement components, receptors and regulators, which act to generate immunoprotective and proinflammatory products. In the present study, human microarray analysis was used to systematically examine the mRNA expression levels of all complement components, receptors and regulators in peripheral blood mononuclear cells (PBMCs) isolated from patients with acute myocardial infarction (AMI), those with SA and clinical controls. The serum levels of CH50, C3 and C4 were also measured in all 300 subjects. The aim of the present in vitro study was to investigate the nature of complement system immunity in the AMI and SA stages of CAD. 


\section{Materials and methods}

Patient information. The present study recruited 100 patients with AMI, 100 patients with SA and 100 clinical controls. Human microarray analysis was performed in 60 individuals, which were randomly selected from the AMI, SA and control groups (20 in each group). The sample sizes, the number of subjects per group, were based on an assumed within-group variance of 0.50 and targeted nominal power of 0.95 (15). The baseline demographic data is shown in Table I. The patients with AMI were admitted $\leq 12 \mathrm{~h}$ following onset of symptoms to the Coronary Care Unit (Tongji Hospital, Shanghai, China) between January and December 2013, and included 88 men and 12 women, with an age of $59 \pm 13$ years (mean \pm standard deviation). The SA group contained 100 patients ( 82 men and 18 women aged $63 \pm 10$ years). As a control group, 100 clinical inpatients ( 80 men and 20 women aged $61 \pm 7$ years) were enrolled during the same period. Histories, physical examination, ECG, chest radiography and routine chemical analyses confirmed the controls had no evidence of CAD.

All patients with AMI were diagnosed on the basis of the following criteria (16): Detection of an increase in cardiac biomarker values, preferably cardiac troponin, with at least one value above the 99th percentile upper reference limit and with at least one of the following: i) Symptoms of ischemia; ii) new or presumed new significant ST-segment-T wave changes or new left bundle branch block; iii) development of pathological Q waves on ECG; iv) imaging evidence of new loss of viable myocardium or new regional wall motion abnormality; v) identification of an intracoronary thrombus on angiography.

All patients with SA had exclusively effort angina with a positive exercise stress test and at least one coronary stenosis detected on angiography ( $>70 \%$ reduction in lumen diameter).

No significant differences were present among the three groups in terms of age, gender, smoking status, body mass index, systolic blood pressure, diastolic blood pressure, low-density lipoprotein cholesterol, high-density lipoprotein cholesterol, triglycerides and fasting plasma glucose.

The exclusion criteria for the three groups were as follows: Venous thrombosis, history of severe renal or hepatic diseases, hematological disorders, acute or chronic inflammatory diseases and malignancy.

The experimental protocol was approved by the ethics committee of Tongji University (Shanghai, China) and informed consent was obtained.

Gene expression chips. Agilent G4112F Whole Human Genome Oligo Microarrays, purchased from Agilent Technologies, Inc. (Santa Clara, CA, USA) were used in the chip analysis. A microarray was composed of $>41,000$ genes or transcripts, including targeted 19,596 entrez gene RNAs. The sequence information used in the microarrays was derived from the latest RefSeq (ncbi.nlm.nih.gov/refseq/), Goldenpath (genekeys.com/33-steps-resources-wheel)/, Ensembl (asia.ensembl.org/index.html) and Unigene (ncbi.nlm.nih.gov/unigene) databases (17). The functions of $>70 \%$ of the genes in the microarray were already known. A total of 60 randomly selected patients were subjected to the chip analysis (20 in each group).
Total RNA isolation. Peripheral blood samples $(10 \mathrm{ml})$ from the median cubital vein were drawn from all patients using a PAXgene ${ }^{\mathrm{TM}}$ tube immediately following admission. Of each blood sample, $5 \mathrm{ml}$ was used for total RNA isolation, and the remainder was used for the detection of $\mathrm{CH} 50, \mathrm{C} 3$ and $\mathrm{C} 4$. Leucocytes were obtained through density gradient centrifugation at $3,000 \times \mathrm{g}$ for $15 \mathrm{~min}$ at $4^{\circ} \mathrm{C}$ with Ficoll solution, and the remaining red blood cells were destroyed using erythrocyte lysis buffer (Qiagen $\mathrm{GmbH}$, Hilden, Germany). Total RNA was extracted and purified using a PAXgene ${ }^{\mathrm{TM}}$ Blood RNA kit (cat. no. 762174; Qiagen $\mathrm{GmbH}$ ) following the manufacturer's protocol. It was further assessed for an RNA integrity number (RIN) to inspect RNA integration using an Agilent Bioanalyzer 2100 (Agilent Technologies, Inc.). The sample was considered qualified when the 2100 RIN and $28 \mathrm{~S} / 18 \mathrm{~S}$ were $\geq 0.7$.

RNA amplification and labeling. RNA quantity was detected using a Nanodrop. The total RNA was amplified using a reverse transcription kit (Bio-Rad Laboratories, Inc., Hercules, CA, USA) and labeled using a Low Input Quick Amp labeling kit, One-Color (cat. no. 5190-2305; Agilent Technologies, Inc.), following the manufacturer's protocol. The Labeled cRNA was purified using an RNeasy mini kit (cat. no. 74,106; Qiagen $\mathrm{GmbH})$.

Microarray hybridization. Each slide was hybridized with $1.65 \mu \mathrm{g}$ Cy3-labeled cRNA using a Gene Expression Hybridization kit (cat. no. 5188-5242; Agilent Technologies, Inc.) in a hybridization oven (cat. no. G2545A; Agilent Technologies, Inc.), following the manufacturer's protocol. After $17 \mathrm{~h}$ of hybridization, the slides were washed in staining dishes (cat. no. 121; Thermo Fisher Scientific, Inc., Waltham, MA, USA) with a Gene Expression Wash Buffer kit (cat. no. 5188-5327; Agilent Technologies, Inc.), according to the manufacturer's protocol.

Chip scan and data acquisition. The slides were scanned using an Agilent Microarray Scanner (cat. no. G2565CA; Agilent Technologies, Inc.) with the following default settings: Dye channel, green; scan resolution, $3 \mu \mathrm{m} ; 20$ bit. Data were extracted using Feature Extraction 10.7 software (Agilent Technologies, Inc.). The raw data were normalized using the Quantile algorithm with GeneSpring 11.0 software (Agilent Technologies, Inc.).

Reverse transcription-quantitative polymerase chain reaction $R T$-qPCR analysis. The spots in the microarray were randomly selected and their expression levels were confirmed using RT-qPCR analysis. Among all the genes with differential expression, three genes were randomly selected and subjected to RT-qPCR analysis, in addition to the housekeeping gene, GAPDH. The following RNA/primer mixture was prepared in each tube: Total RNA $5 \mu \mathrm{g}$, random hexamers $(50 \mathrm{ng} / \mu \mathrm{l})$ $3 \mu \mathrm{l}, 10 \mathrm{mM}$ dNTP mix $1 \mu \mathrm{l}$ and DEPC $\mathrm{H}_{2} \mathrm{O}$ to $10 \mu \mathrm{l}$. The samples were then incubated at $65^{\circ} \mathrm{C}$ for $5 \mathrm{~min}$ and then on ice for at least $1 \mathrm{~min}$. Next, the reaction master mixture was prepared. For each reaction, the components were as follows: 10 x RT buffer $2 \mu \mathrm{l}, 25 \mathrm{mM} \mathrm{MgCl}_{2} 4 \mu \mathrm{l}, 0.1 \mathrm{M}$ DTT $2 \mu \mathrm{l}$ and RNAaseOUT $1 \mu$ l. The reaction mixture was added 
Table I. Baseline demographic data of the patients in the AMI, SA and Con groups.

\begin{tabular}{|c|c|c|c|c|c|}
\hline \multirow[b]{2}{*}{ Index } & \multirow[b]{2}{*}{ AMI $(n=100)$} & \multirow[b]{2}{*}{$\mathrm{SA}(\mathrm{n}=100)$} & \multirow[b]{2}{*}{ Con $(n=100)$} & \multicolumn{2}{|c|}{ P-value } \\
\hline & & & & Total & AMI, vs. SA \\
\hline Age & $58.6 \pm 12.7$ & $63.6 \pm 11.1$ & $61.1 \pm 7.4$ & 0.542 & 0.211 \\
\hline Gender (M/F) & $88 / 12$ & $82 / 18$ & $80 / 20$ & 0.16 & 0.08 \\
\hline BMI $\left(\mathrm{kg} / \mathrm{m}^{2}\right)$ & $24.6 \pm 2.9$ & $22.5 \pm 2.2$ & $22.7 \pm 1.9$ & 0.112 & 0.76 \\
\hline Ethnicity, Han & 100 & 100 & 100 & 1 & 1 \\
\hline Tobacco (no./day) & $13.8 \pm 10.4$ & $12.4 \pm 8.6$ & $11.2 \pm 8.1$ & 0.134 & 0.448 \\
\hline $\mathrm{SBP}(\mathrm{mmHg})$ & $130 \pm 11$ & $123 \pm 10$ & $122 \pm 7$ & 0.147 & 0.721 \\
\hline DBP (mmHg) & $67 \pm 9$ & $72.0 \pm 9$ & $77 \pm 4$ & 0.121 & 0.094 \\
\hline LDL-C (mmol/l) & $2.2 \pm 1.3$ & $2.3 \pm 1.7$ & $2.6 \pm 1.5$ & 0.123 & 0.576 \\
\hline Triglycerides (mmol/l) & $1.4 \pm 1.6$ & $1.6 \pm 1.1$ & $1.7 \pm 0.8$ & 0.22 & 0.132 \\
\hline HDL-C (mmol/l) & $0.7 \pm 0.9$ & $0.8 \pm 0.6$ & $1.0 \pm 0.2$ & 0.067 & 0.103 \\
\hline FBG (mmol/l) & $5.4 \pm 0.1$ & $5.3 \pm 0.9$ & $5.1 \pm 0.2$ & 0.094 & 0.334 \\
\hline
\end{tabular}

Data are presented as the mean \pm standard deviation. BMI, body mass index; SBP, systolic blood pressure; DBP, diastolic blood pressure; LDL-C, low-density lipoprotein cholesterol; HDL-C, high-density lipoprotein cholesterol; FBG, fasting plasma glucose; AMI, acute myocardial infarction; SA, stable angina pectoris; Con, control.

to the RNA/primer mixture was mixed briefly, and then placed at room temperature for $2 \mathrm{~min}$. Next, $1 \mu 1(50 \mathrm{U})$ of SuperScript II RT was added to each tube, mixed and incubated at $25^{\circ} \mathrm{C}$ for $10 \mathrm{~min}$. The tubes were then incubated at $42^{\circ} \mathrm{C}$ for $50 \mathrm{~min}$, heat inactivated at $70^{\circ} \mathrm{C}$ for $15 \mathrm{~min}$, and chilled on ice. Then, $1 \mu \mathrm{l}$ RNase $\mathrm{H}$ was added and incubated at $37^{\circ} \mathrm{C}$ for $20 \mathrm{~min}$. The 1 st strand cDNA was stored at $-20^{\circ} \mathrm{C}$ until. PCR thermocycling conditions were as follows: $50^{\circ} \mathrm{C} 2 \mathrm{~min}, 1$ cycle, $95^{\circ} \mathrm{C}$ for $10 \mathrm{~min} 1 \mathrm{cycle}, 95^{\circ} \mathrm{C}$ for $15 \mathrm{sec}, 60^{\circ} \mathrm{C}$ for $30 \mathrm{sec}, 72^{\circ} \mathrm{C}$ for $30 \mathrm{sec}, 40 \mathrm{cycles}$ and $72^{\circ} \mathrm{C}$ for $10 \mathrm{~min}, 1$ cycle. The relative expression was indicated as the expression of the target gene normalized to the expression of GAPDH $\left(2^{-\Delta \Delta C q}\right)$. Melting curve analysis and the $2^{-\Delta \Delta \mathrm{Cq}}$ method (18) were used to detect differences in the levels of expression among the three groups. The results from the RT-qPCR analysis were consistent with the microarray analysis.

Laboratory assays. The remaining $5 \mathrm{ml}$ blood sample was centrifuged at $3,000 \times \mathrm{g}$ for $15 \mathrm{~min}$ at $4^{\circ} \mathrm{C}$ within $1 \mathrm{~h}$ to obtain the serum. Following collection, the tubes were placed on ice in order to avoid complement inactivation, followed by immediate analyses. CH50 was detected using a liposome immune assay on a Beckman DxC-800 fully automatic biochemical analyzer (Beckman Coulter, Inc., Brea, CA, USA; reagents from Wako Pure Chemical Industries, Ltd., Osaka, Japan). C3 and C4 were detected using immunonephelometry (BNII system; Siemens AG, Munich, Germany; reagents, Siemens Healthcare Diagnostics Products GmbH, Marburg, Germany). The reference intervals were as follows: $\mathrm{CH} 50,23-46 \%$; $\mathrm{C} 3,0.9-1.8 \%$ and $\mathrm{C} 4$, $0.1-0.4 \%$.

Statistical analysis. Descriptive statistical data are expressed as the mean \pm standard deviation. Differences between groups were examined using one-way analysis of variance, following which all pairwise group mean comparisons were performed using Tukey's method. Density curves for CH50, C3 and C4

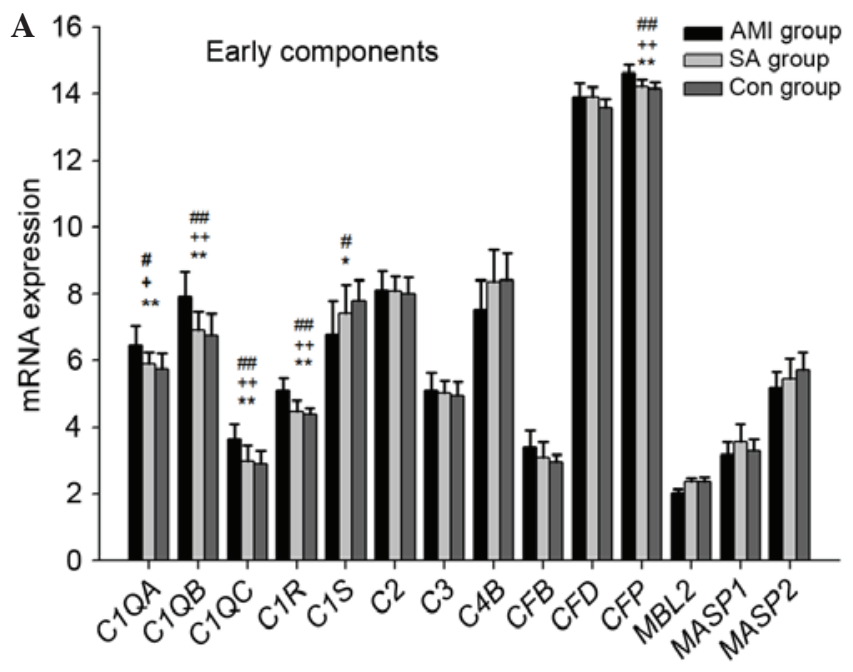

B

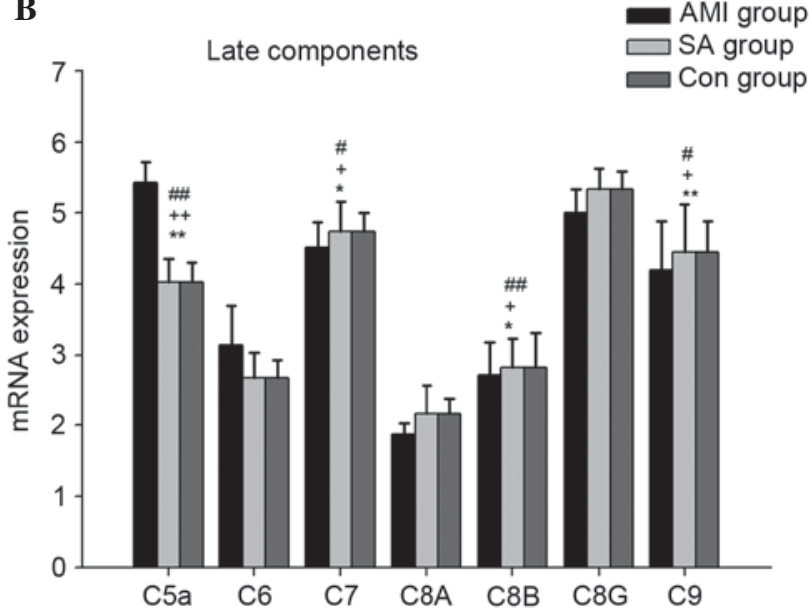

Figure 1. mRNA expression of complement components. (A) Early and (B) late complement components in peripheral blood mononuclear cells. ${ }^{*} \mathrm{P}<0.05$ and ${ }^{* *} \mathrm{P}<0.01$ among the three groups; ${ }^{~} \mathrm{P}<0.05$ and ${ }^{\# \#} \mathrm{P}<0.01 \mathrm{AMI}$, vs. Con; ${ }^{+} \mathrm{P}<0.05$ and ${ }^{++} \mathrm{P}<0.01 \mathrm{AMI}$, vs. SA. AMI, acute myocardial infarction; SA, stable angina pectoris; Con, control. 
Table II. Levels of CH50, C3 and C4 among the AMI, SA and Con groups.

P-value

\begin{tabular}{lcccrrrr}
\cline { 6 - 8 } Index & AMI $(\% ; \mathrm{n}=100)$ & SA $(\% ; \mathrm{n}=100)$ & Con $(\% ; \mathrm{n}=100)$ & Total & AMI, vs. Con & SA, vs. Con & AMI, vs. SA \\
\hline CH50 & $46.60 \pm 0.77$ & $43.10 \pm 0.70$ & $34.10 \pm 0.52$ & $<0.001$ & $<0.001$ & $<0.001$ & 0.003 \\
C3 & $1.46 \pm 0.47$ & $1.40 \pm 0.38$ & $1.27 \pm 0.27$ & 0.001 & 0.001 & 0.016 & 0.609 \\
C4 & $0.27 \pm 0.05$ & $0.26 \pm 0.05$ & $0.24 \pm 0.07$ & $<0.001$ & 0.001 & 0.028 & 0.391 \\
\hline
\end{tabular}

Data are presented as the mean \pm standard deviation. AMI, acute myocardial infarction; SA, stable angina pectoris; Con, control.

$\mathbf{A}$
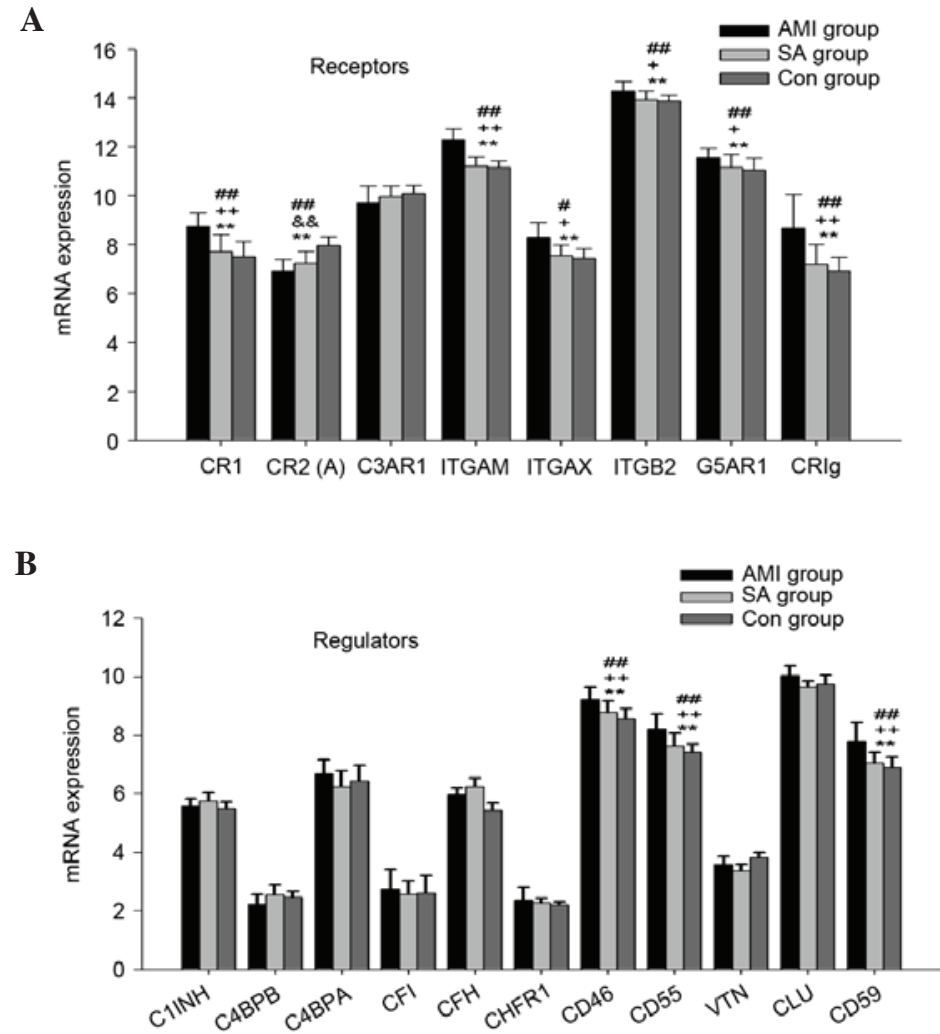

Figure 2. Comparison of mRNA expression levels. mRNA expression levels of (A) complement receptors and (B) regulators were compared in PBMCs from the three groups. ${ }^{*} \mathrm{P}<0.05$ and ${ }^{* *} \mathrm{P}<0.01$ among the three groups; ${ }^{\#} \mathrm{P}<0.05$ and ${ }^{\#} \mathrm{P}<0.01 \mathrm{AMI}$, vs. Con; ${ }^{+} \mathrm{P}<0.05$ and ${ }^{++} \mathrm{P}<0.01 \mathrm{AMI}, \mathrm{vs}$. $\mathrm{SA} ;{ }^{\circledR} \mathrm{P}<0.05$ and ${ }^{\&} \& \mathrm{P}<0.01$ SA, vs. Con. AMI, acute myocardial infarction; SA, stable angina pectoris; Con, control.

were delineated using R version 3.1.3 software (r-project.org). Data were analyzed using SPSS 17.0 (SPSS, Inc., Chicago, IL, USA). $\mathrm{P}<0.05$ was considered to indicate a statistically significant difference

\section{Results}

Gene expression of complement components. The results showed that early complement components, including $\mathrm{C} 1 \mathrm{q} \alpha$, C1q $\beta$, C1q $\gamma, C 1 r, C 1 s, C 2, C 3$, C4b, Factor B, Factor D, Factor $\mathrm{P}, \mathrm{MBL}, \mathrm{MASP} 1$, and MASP2 were expressed in the PBMCs from the three groups of patients (Fig. 1A). In the PBMCs from the three groups, the expression levels of genes encoding $\mathrm{C} 1 \mathrm{q} \alpha, \mathrm{C} 1 \mathrm{q} \beta, \mathrm{Clq} \gamma, \mathrm{C} 1 \mathrm{r}$, Factor P and $\mathrm{C} 1 \mathrm{~s}$ were significantly different $(\mathrm{P}<0.05)$. In the AMI group, the gene expression levels of $\mathrm{C} 1 \mathrm{q} \alpha(\mathrm{P}<0.05), \mathrm{C} 1 \mathrm{q} \beta, \mathrm{C} 1 \mathrm{q} \gamma, \mathrm{C} 1 \mathrm{r}$ and Factor $\mathrm{P}$ (all
$\mathrm{P}<0.01$ ), were significantly upregulated, compared with those in the SA group and control group, respectively, whereas the mRNA expression of C1s in the AMI group was downregulated $(\mathrm{P}<0.05)$, compared with that in the control group. The gene expression levels of MBL, MASP1 and MASP2 were lowest in the AMI group among the three groups.

The gene expression levels of late complement components, including $\mathrm{C} 5 \mathrm{a}, \mathrm{C} 6, \mathrm{C} 7, \mathrm{C} 8 \alpha, \mathrm{C} 8 \beta, \mathrm{C} 8 \gamma$ and $\mathrm{C} 9$, were also examined in the PBMCs from the three groups (Fig. 1B). In the AMI group, the mRNA expression of C5a was significantly upregulated $(\mathrm{P}<0.01)$, whereas the expression levels of $\mathrm{C} 7$, C8 $\beta$ and C9 were significantly downregulated, compared with those in the SA and control groups, respectively $(\mathrm{P}<0.05)$. However, no significant differences were found in the mRNA expression of early or late complement components between the SA and control groups. 
A

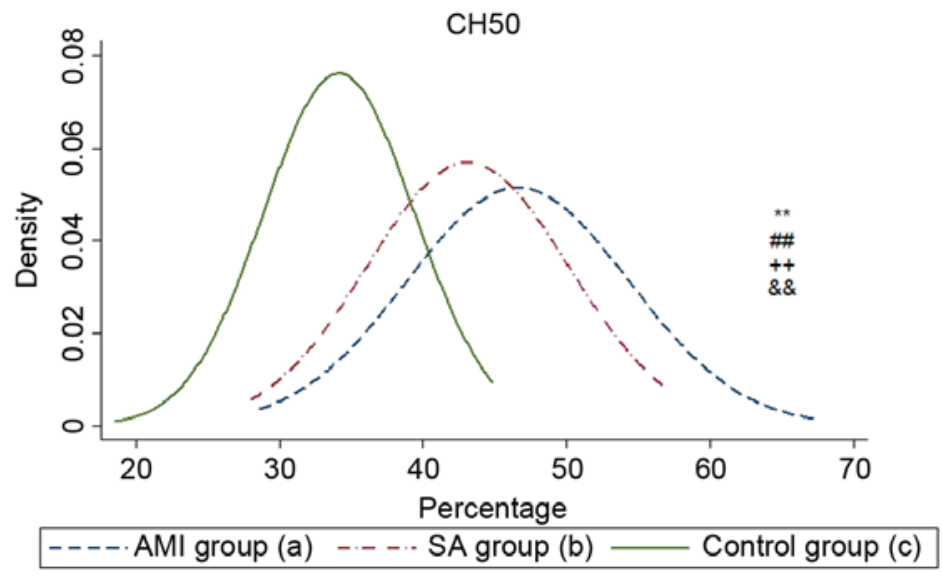

B

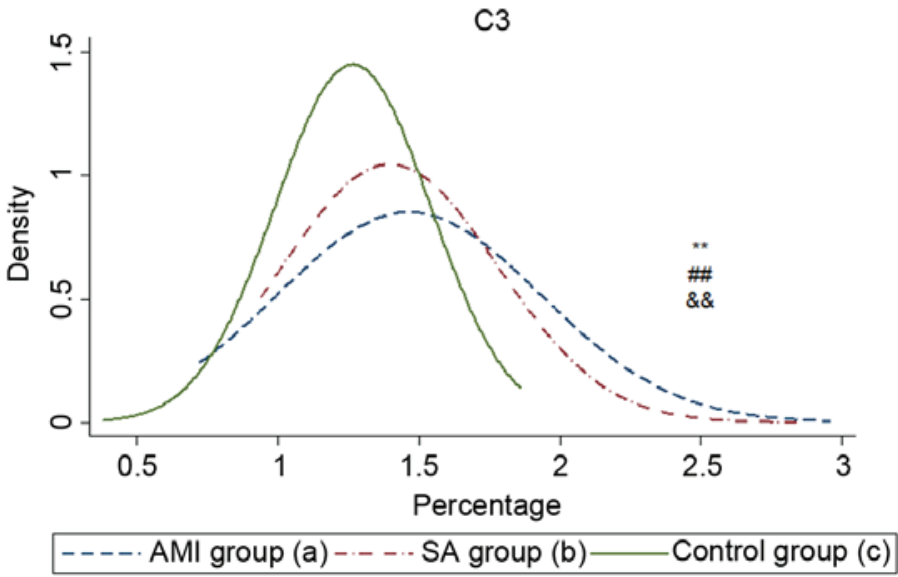

C

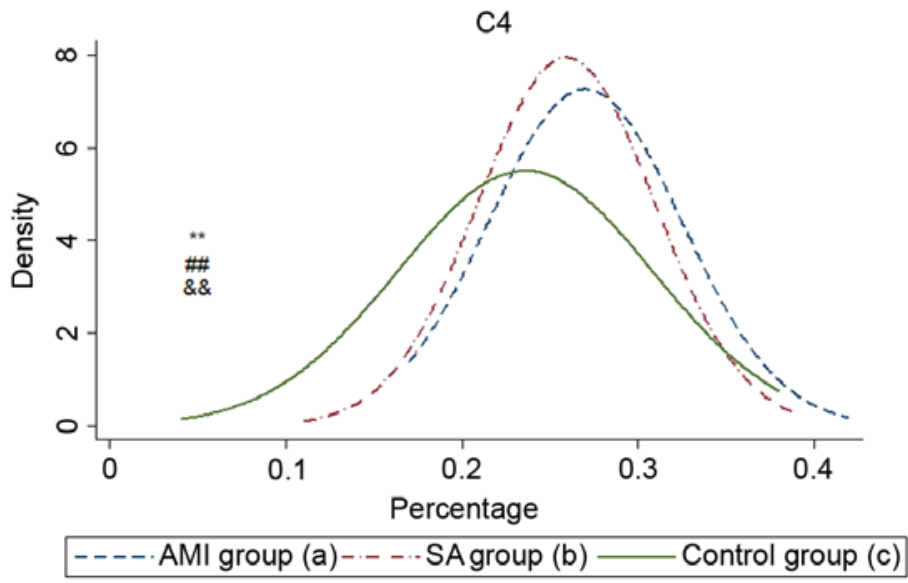

Figure 3. Serum complement levels in PBMCs from the three groups. Levels of (A) CH50, (B) C3 and (C) C4. ${ }^{*} \mathrm{P}<0.05$ and ${ }^{* *} \mathrm{P}<0.01$ among the three groups; ${ }^{\#} \mathrm{P}<0.05$ and ${ }^{\# \#} \mathrm{P}<0.01$ AMI, vs. Con; ${ }^{+} \mathrm{P}<0.05$ and ${ }^{++} \mathrm{P}<0.01$ AMI, vs. SA; ${ }^{\circledR} \mathrm{P}<0.05$ and ${ }^{\& \&}: \mathrm{P}<0.01 \mathrm{SA}$, vs. Con. AMI, acute myocardial infarction; SA, stable angina pectoris; Con, control.

Gene expression of complement receptors. The mRNA expression of complement receptors, including CR1, CR2, $\mathrm{C} 3 \mathrm{aR}$, integrin $\alpha \mathrm{M}$, integrin $\alpha \mathrm{X}$, integrin $\beta 2, \mathrm{C} 5 \mathrm{aR}$ and CRIg were also examined in the PBMCs from the three groups (Fig. 2A). CR3 consists of integrin $\alpha \mathrm{M}$ and integrin $\beta 2$, and CR4 comprises integrin $\alpha X$ and integrin $\beta 2$. In the PBMCs from the three groups, the expression levels of the genes encoding CR1, CR2, integrin $\alpha M$, integrin $\alpha X$, integrin $\beta 2$, $\mathrm{C} 5 \mathrm{aR}$ and CRIg were significantly different $(\mathrm{P}<0.01)$. In the AMI group, the mRNA expression levels of CR1, integrin $\alpha \mathrm{M}$, integrin $\alpha X$, integrin $\beta 2, C 5 \mathrm{aR}$ and CRIg were significantly higher, compared with those in the SA and control groups $(\mathrm{P}<0.05)$. The mRNA expression of $\mathrm{CR} 2$ was significantly downregulated in the AMI and SA groups, compared with that in the control group $(\mathrm{P}<0.01)$.

Gene expression of complement regulators. The gene expression levels of complement regulators, including $\mathrm{C} 1$ inhibitory factor (C1INH), C4b binding protein $\alpha(\mathrm{C} 4 \mathrm{~b} \alpha), \mathrm{C} 4 \mathrm{~b}$ binding protein $\beta(\mathrm{C} 4 \mathrm{~b} \beta)$, Factor I, Factor H, Factor H-related protein 1 (CFHR-1), CD46 (MCP), CD55 (DAF), vitronectin (VTN), clusterin (CLU) and CD59 (MIRL) were detected 
in PBMCs from the three groups of patients (Fig. 2B). The mRNA levels of CD46, CD55 and CD59 were significantly different among the three groups $(\mathrm{P}<0.01)$. In the PBMCs from the AMI group, the expression levels of genes encoding CD46, CD55 and CD59 were significantly higher, compared with those in the other two groups $(\mathrm{P}<0.01)$. No significant differences were found in the gene expression of complement regulators between the SA and control groups.

Serum levels of complement components. The serum levels of $\mathrm{CH} 50, \mathrm{C} 3$ and $\mathrm{C} 4$ were significantly increased in the AMI and SA groups, compared with the control group (Table II). The level of CH50 in the AMI group was higher, compared with that in the SA group $(\mathrm{P}<0.01)$. No significant differences were found between the AMI and SA groups in the levels of $\mathrm{C} 3$ or $\mathrm{C} 4$. The density curves of $\mathrm{CH} 50, \mathrm{C} 3$ and $\mathrm{C} 4$ are shown in Fig. 3A-C.

\section{Discussion}

In the present study, the early complement components of three complement pathways were examined, and it was found that the mRNA levels of C1q $\alpha, C 1 q \beta, C 1 q \gamma$ and $C 1 r$ were significantly upregulated in patients with AMI, compared with patients with SA patients and controls (Fig. 1). The upregulation of the mRNA levels of C1q $\alpha, \mathrm{Clq} \beta, \mathrm{Clq} \gamma$ and $\mathrm{C} 1 \mathrm{r}$ suggested that the classical pathway, which is typically initiated by $\operatorname{IgM}$ or IgG-antibody/antigen immune complexes, was activated in the patients with AMI (19). The alternative pathway is activated predominantly by 'foreign surfaces', through factor $\mathrm{P}$ and the spontaneous hydrolysis of C3-C3b. In the present study, the expression of factor $\mathrm{P}$ in the AMI group was significantly higher, compared with the other two groups, indicating that the alternative pathway may also have been activated. The activation of the classical and alternative pathways in the present study was consistent with the results from previous clinical studies $(10,11,19)$. When mannose-bind lectin (MBL) or ficolin bind to carbohydrate on the surface of a pathogen, the MBL-associated serine proteases (MASPs) are activated, following which then the lectin pathway is activated (20). Previous studies have shown that individuals with MBL and MBL-associated MASP deficiencies have immune dysfunction and are susceptible to exotic pathogens (21-24). In the present study, the gene expression levels of MBL, MASP1 and MASP2 were lowest in the patients with AMI among the three groups, therefore, the downregulated expression of these three genes indicated decreased lectin pathway activity in the AMI group.

Three distinct pathways share a common terminal access to form the C5b-9 complex (MAC), which forms a transmembrane pore in the target cell membrane that causes cell lysis and death. C5b initiates the formation of the MAC, which consists of $\mathrm{C} 5 \mathrm{~b}, \mathrm{C} 6, \mathrm{C} 7, \mathrm{C} 8$ and multiple molecules of C9. In the results of the present study, the expression of seven late complement component genes was detected, and five of these, including the $\mathrm{C} 7, \mathrm{C} 8 \alpha, \mathrm{C} 8 \beta, \mathrm{C} 8 \gamma$ and $\mathrm{C} 9 \mathrm{mRNAs}$ were lowest in the patients with AMI. The significant decline in the gene expression levels of C7, C8 and C9 in patients with AMI may inhibit MAC formation.

The present study also examined the gene expression levels of eight complement receptors (Fig. 2A), and the mRNA levels of CR1, CR3, CR4, C5aR and CRIg were significantly higher in the AMI group among the three groups. This suggested that the interactions between certain complement effector molecules, including $\mathrm{C} 3 \mathrm{~b}, \mathrm{C} 4 \mathrm{~b}$, ic $3 \mathrm{~b}, \mathrm{c} 3 \mathrm{~d}$ and $\mathrm{c} 3 \mathrm{c}$, and their receptors were enhanced, and that the complement effectors were involved in opsonization and phagocytosis, also promoted the mobilization, migration and proliferation of leukocytes The mRNA expression levels of CR2 in the AMI and SA groups were significantly downregulated, compared the control group. CR2 is a B cell membrane glycoprotein, which is involved in $\mathrm{B}$ cell activation, survival and proliferation. In addition, CR2 is important in the recognition of foreign DNA from bacterium, viruses and other pathogens during host-immune responses $(25,26)$. In the present study the gene expression levels of CR2 were significantly downregulated in the AMI and SA groups, suggesting possible immune dysfunction in the $\mathrm{B}$ cells, and the potential increased risk of infections in patients with AMI and SA.

The gene expression levels of eleven complement regulators were also detected in the present study (Fig. 2B). The results showed that the mRNA expression levels of CD46, CD55 and CD59 were significantly upregulated in the AMI group. CD46, a known cofactor protein, acts as a cofactor for factor I in the degradation of $\mathrm{C} 3 \mathrm{~b}$ and $\mathrm{C} 4 \mathrm{~b}$, and inhibits convertase formation. CD55, a decay accelerating factor, prevents the formation of new C3 and C5 convertases and accelerates the decay of preformed C3 and C5 convertases. CR1 belongs to the regulators of complement activation protein family, and exhibits CD46 and CD55 activities (27). CD59 is a key regulator of MAC assembly and restricts the formation of MAC (28-30). The upregulated gene expression levels of CR1, CD46, CD55 and CD59 in the patients with AMI suggested the inhibition of MAC formation.

The plasma levels of $\mathrm{CH} 50, \mathrm{C} 3$ and $\mathrm{C} 4$, which reflect the activities of C1-C9 via the classical pathway, were all elevated in the AMI and SA groups. By analyzing the levels of genes and proteins in the present study, complement was found to be activated in the AMI and SA patient groups. However, the differential mRNA expression of complement components, receptors and regulators in AMI suggested that the inhibition of the C5b-9 complex induced cell lysis. The depression of cytolytic effects in the complement system in patients with AMI may be associated with the pathogenesis of AMI. As a consequence, improving complement-mediated innate immunity may be considered as a potential target for medical interventions in patients with AMI.

\section{Acknowledgements}

This study was supported by the Shanghai Traditional Chinese Medicine 3-year Development Program (grant no. 2014-2016), the Shanghai Health Bureau (grant no. 20144Y0046) and the National Natural Science Fund (grant no. 81570359).

\section{References}

1. Institute of Medicine (US) Committee on Preventing the Global Epidemic of Cardiovascular Disease: Meeting the Challenges in Developing Countries; Fuster V, Kelly BB, editors.Promoting cardiovascular health in the developing world: A critical challenge to achieve global health. National Academies Press, Washington (DC): 2010. 
2. Evora PR, Nather J, Tubino PV, Albuquerque AA, Celotto AC and Rodrigues AJ: Curbing inflammation in the ischemic heart disease. Int J Inflam 2013: 183061, 2013.

3. Patzelt J, Verschoor A and Langer HF: Platelets and the complement cascade in atherosclerosis. Front Physiol 6: 49, 2015

4. Diepenhorst GM, van Gulik TM and Hack CE: Complement-mediated ischemia-reperfusion injury: Lessons learned from animal and clinical studies. Ann Surg 249:889-899, 2009.

5. Speidl WS, Kastl SP, Huber K and Wojta J: Complement in atherosclerosis: Friend or foe? J Thromb Haemost 9: 428-440, 2011

6. Esser AF: The membrane attack complex of complement assembly, structure and cytotoxic activity. Toxicology 87 : 229-247, 1994

7. Francescut L, Steiner T, Byrne S, Cianflone K, Francis S and Stover C: The role of complement in the development and manifestation of murine atherogenic inflammation: Novel avenues. J Innate Immun 4: 260-272, 2012.

8. Széplaki G, Varga L, Füst G and Prohászka Z: Role of complement in the pathomechanism of atherosclerotic vascular diseases. Mol Immunol 46: 2784-2793, 2009.

9. Cubedo J, Padró T and Badimon L: Coordinated proteomic signature changes in immune response and complement proteins in acute myocardial infarction: The implication of serum amyloid P-component. Int J Cardiol 168: 5196-5204, 2013.

10. Mihlan M, Blom AM, Kupreishvili K, Lauer N, Stelzner K, Bergström F, Niessen HW and Zipfel PF: Monomeric C-reactive protein modulates classic complement activation on necrotic cells. FASEB J 25: 4198-4210, 2011.

11. Giasuddin ASM, ElMahdawi JM and ElHassadi FM: Serum complement $(\mathrm{C} 3, \mathrm{C} 4)$ levels in patients with acute myocardia infarction and angina pectoris. Bangladesh Med Res Counc Bull 33: 98-102, 2007.

12. Iltumur K, Karabulut A, Toprak G and Toprak N: complement activation in acute coronary syndromes. APMIS 113: 167-174,2005.

13. Kostner KM,Fahti RB, Case C,Hobson P, Tate J and Marwick TH: Inflammation, complement activation and endothelial function in stable and unstable coronary artery disease. Clin Chim Acta 365 129-134, 2006.

14. Yasuda M, Takeuchi K, Hiruma M, Iida H, Tahara A, Itagane H, Toda I, Akioka K, Teragaki M, Oku H, et al: The complement system in ischemic heart disease. Circulation 81: 156-163, 1990.

15. Dobbin K and Simon R: Sample size determination in microarray experiments for class comparison and prognostic classification. Biostatistics 6: 27-38, 2005.

16. Thygesen K, Alpert JS, Jaffe AS, Simoons ML, Chaitman BR, White HD; Joint ESC/ACCF/AHA/WHF Task Force for Universal Definition of Myocardial Infarction; Authors/Task Force Members Chairpersons, Thygesen K and Alpert JS Third universal definition of myocardial infarction. J Am Coll Cardiol 60: 1581-1598, 2012
17. Wiltgen M and Tilz GP: DNA microarray analysis: Principles and clinical impact. Hematology 12: 271-287, 2007.

18. Livak KJ and Schmittgen TD: Analysis of relative gene expression data using real-time quantitative PCR and the 2(-Delta Delta C(T)) Method. Methods 25: 402-408, 2001.

19. Horváth Z, Csuka D, Vargova K, Kovács A, Molnár ÁA, Gulácsi-Bárdos P, Leé S, Varga L, Kiss RG, Préda I and Füst G: Elevated $\mathrm{C} 1 \mathrm{rClsC}$ inh levels independently predict atherosclerotic coronary heart disease. Mol Immunol 54: 8-13, 2013.

20. Takahashi M, Mori S, Shigeta S and Fujita T: Role of MBL-associated serine protease (MASP) on activation of the lectin complement pathway. In Adv Exp Med Biol 598: 93-104, 2007.

21. Pesonen E, Hallman M, Sarna S, Andsberg E, Haataja R, Meri S, Persson K, Puolakkainen M, Ohlin H and Truedsson L: Mannose-binding lectin as a risk factor for acute coronary syndromes. Ann Med 41: 591-598, 2009.

22. Koch A, Melbye M, Sørensen P, Homøe P, Madsen HO, Mølbak K, Hansen CH, Andersen LH, Hahn GW and Garred P: Acute respiratory tract infections and mannose-binding lectin insufficiency during early childhood. JAMA 285: 1316-1321, 2001.

23. Peterslund NA, Koch C, Jensenius JC and Thiel S: Association between deficiency of mannose-binding lectin and severe infections after chemotherapy. Lancet 358: 637-638, 2001.

24. Ali YM, Lynch NJ, Haleem KS, Fujita T, Endo Y, Hansen S, Holmskov U, Takahashi K, Stahl GL, Dudler T, et al: The lectin pathway of complement activation is a critical component of the innate immune response to pneumococcal infection. PLoS Pathog 8: e1002793, 2012

25. Low HZ, Hilbrans D, Schmidt-Wolf IG and Illges H: Enhanced CD21 expression and shedding in chronic lymphatic leukemia: A possible pathomechanism in disease progression. Int J Hematol 96: 350-356, 2012.

26. Asokan R, Banda NK, Szakonyi G, Chen XS and Holers VM: Human complement receptor $2(\mathrm{CR} 2 / \mathrm{CD} 21)$ as a receptor for DNA: Implications for its roles in the immune response and the pathogenesis of systemic lupus erythematosus (SLE). Mol Immunol 53: 99-110, 2013.

27. Nuutila J, Jalava-Karvinen P, Hohenthal U, Kotilainen P, Pelliniemi TT and Nikoskelainen J: Use of complement regulators, CD35, CD46, CD55 and CD59, on leukocytes as markers for diagnosis of viral and bacterial infections. Hum Immunol 74: 522-530, 2013.

28. Huang Y, Qiao F, Abagyan R, Hazard S and Tomlinson S: Defining the CD59-C9 binding interaction. J Biol Chem 281: 27398-27404, 2006.

29. Mayilyan KR: Complement genetics, deficiencies and disease associations. Protein Cell 3: 487-496, 2012.

30. Wu G, Hu W, Shahsafaei A, Song W, Dobarro M, Sukhova GK, Bronson RR, Shi GP, Rother RP, Halperin JA and Qin X: Complement regulator CD59 protects against atherosclerosis by restricting the formation of complement membrane attack complex. Circ Re 104: 550-558, 2009. 